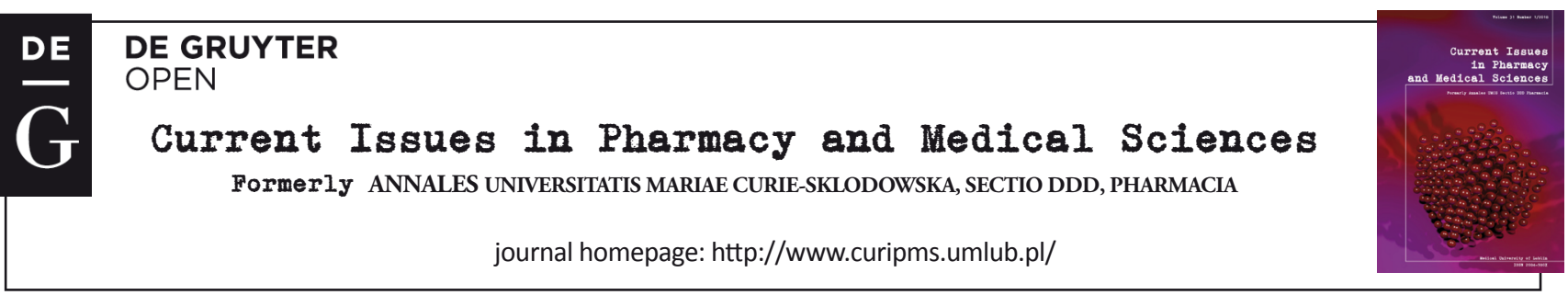

\title{
New drugs - from necessity to delivery
}

\author{
Ewa KedZierska ${ }^{1 \star}$, Lila Dabkowska ${ }^{1}$, Tomasz Krzanowski ${ }^{2}$, Ewa Gibula ${ }^{1}$, \\ Jolanta Orzelska-Gorka ${ }^{1}$, Monika WujeC ${ }^{2}$
}

\begin{abstract}
${ }^{1}$ Department of Pharmacology and Pharmacodynamics, Medical University of Lublin, Chodzki 4A, 20-093 Lublin, Poland
2 Department of Organic Chemistry, Medical University of Lublin, Chodzki 4A, 20-093 Lublin, Poland
\end{abstract}

\begin{tabular}{ll}
\hline ARTICLE INFO & ABSTRACT \\
$\begin{array}{ll}\text { Received 24 March 2018 } \\
\text { Accepted 29 April 2018 }\end{array}$ & $\begin{array}{l}\text { How to get a new drug to market? How much time does it take to go from the idea } \\
\text { to implementation? In this study we followed the path drugs take from synthesis to } \\
\text { introduction to the market. In doing so, articles in the PubMed and the Google Scholar } \\
\begin{array}{l}\text { Keywords: } \\
\text { drug design, } \\
\text { lead compound, } \\
\text { preclinical trials, } \\
\text { clinical trials. }\end{array}\end{array} \quad \begin{array}{l}\text { database have been analyzed using the keywords: drug development, drug design, lead } \\
\text { compound, preclinical trials, clinical trials. The available literature was subjectively } \\
\text { selected due to its usefulness in the topic. Based on the obtained articles, we presented } \\
\text { the stages that a would-be drug takes on the way from the idea to marketing. Herein, it is } \\
\text { underlined that the process of creating new drugs is long, extremely labor-intensive, and } \\
\text { involves many restrictions in the context of the use of animals, as well as humans. }\end{array}$ \\
\hline
\end{tabular}

\section{INTRODUCTION}

The search for medicines had accompanied humanity for the whole duration of its existence. Archeology, for example, provides evidence of prehistoric Americans using peyote - small cacti containing psychoactive alkaloids, particularly mescaline [1]. In ancient Europe, even modern man's ancestors had been curing diseases with medicines derived from plants, animals and minerals. Indeed, even the idea of a pharmacopoeia goes back to about $300 \mathrm{BC}$ - that written by Theophrastus of Eresus [2].

In the mid-nineteenth century, the situation underwent drastic change, because scientists at that applied scientific method to isolate and purify the active principles of those remedies. Because of these efforts, many naturally occurring substances have been synthesized and their structures determined (e.g. morphine from opium, cocaine from coca leaves) [3].

Still, the vast majority of known drugs used nowadays had been discovered during the last century because of rapid progress in fields of pharmacology and toxicology. It is very important for contemporary medicine to create new drugs, ones more efficient than currently marketed. The most favorable situation exists when a new drug is effective in the treatment of a previously incurable disease. However, often the scientists must be satisfied with the discovery of a drug that simplifies or improves existing treatment [4].
A crucial step in this search is the potential synthesis or isolation of the active compound. This is then subjected to further tests after determination of the structure and chemical properties. In every phase of the research, there is the need to reckon with the necessity to abstain from further experiments due to inappropriate pharmacological effect. It is estimated that from the 8000-10000 tested substances, only one passes on to being used in treatment [5].

Traditional methods of discovering new drugs rely on testing thousands of natural substances and finding the one that will affect a suitable target. This procedure resembles looking for a needle in a hay stack. Unfortunately, it is very laborious and expensive [6].

The expected activity of the new substances is relatively uncertain, and because of that, they have to pass a series of screening tests aimed at understanding their activities. Oftentimes, the pharmacological activity of a drug is discovered by accident. A good example is Viagra (sildenafil). The drug company, Pfizer, was conducting clinical trials on a new drug for angina, but the results were not satisfactory. The company was close to refraining from further tests when volunteers began to talk about about an unexpected side effect - lots of erection. This observation led to the marketing of a drug used by millions of men [7].

Over the years, the perception of what is a drug has been changed. The most significant is that scientists have stopped looking at medicine as an anonymous collection of atoms, and started seeing it as a steric (shape of particles) with

\footnotetext{
* Corresponding author

e-mail: ewa.kedzierska@umlub.pl
} 
electrostatic interactions, of hydrophilic and hydrophobic activity - in other words, a substance with directional interactions in three-dimensional space. Therefore, it is important that while random synthesis are still continued to be performed, the testing of the resulting substances is more accurate and has been extended by new methods of analysis [8].

Currently, industrial and academic researchers begin the search for new drugs by identifying suitable targets in the body and designing the structure to interact with that target. Knowledge about functioning of the target and its reaction with the potential drug is essential.

\section{CHOOSING A DISEASE}

The first stage of the process of designing a new drug is choosing a disease. The drug developer has to take into account both medical and financial factors. Due to the latter, most of the research is concerned with the diseases of the Western world (e.g. obesity, ulcers, migraine, cancer, depression), because this market provides the greatest return on investment. Once the developer's market strategists choose the disease, the next step for the scientists is to find a suitable drug target [3]. Defining the cause of the disease plays a crucial role in this process. The majority of diseases, or at least their symptoms, results from disruption of homeostasis.

\section{SELECT A DRUG TARGET}

Most diseases, except those caused by infections or traumas, have a genetic background. The map of genetic variation determines an individual's ability to cope with various illnesses, his or her susceptibility to pathogens, and response to drugs. Therefore, modern drug design strategy begins with research into the functioning of the human body, both in health and disease. The goal is to stop the disease process at the cellular level. Drugs can be precisely designed to interact with the source of the disease [9]. Drug targets are usually proteins or glycoproteins, as proteins are the components of the enzymes and receptors with which the drugs react. So far, only about 500 proteins have been identified as destinations for all medicines available on the market, however, human genome research gives the opportunity to search for new targets for medicines being designed. Radioligands are most commonly used to identify the drug targets. Nowadays, expressed sequences tag (EST), gene plates and computerized methods (in silico) are becoming more commonly used [10].

High hopes can be attributed to the use of orphan receptors as destinations. This is a specific group of receptors that, based on sequence similarity, can be said to be receptors, but their binding ligand has not yet been found. The search for ligands of orphaned nuclear receptors has led to the discovery of multiple signaling pathways, and has shown a direct connection of nuclear receptors to human diseases such as diabetes, obesity and neurodegenerative diseases [11]. For example, an orphan TLX receptor may be a potential drug target in the treatment of neurodegenerative diseases, and it has been demonstrated that TLX plays a crucial role in regulating the maintenance and self-renewal of adult nerve cells.
Because of this, TLX ligands will be important modulators of neurogenesis and neuronal regeneration [12].

\section{LOOKING FOR A LEAD COMPOUND}

Obtaining knowledge about a particular receptor or enzyme allows to identify the lead compound. This compound does not have to have strong activity, it can exhibit side-effects, as it is a starting point in the search for a new drug. In times past, natural resources and ethnomedicine were a source of lead compounds of many currently used drugs. For example, cocaine became a basis for synthesis of its analogues, which are used as local anesthetics. Similarly, bacteria and fungi contributed to obtaining numerous therapeutic substances, among others: cephalosporins, tetracyclines, rifamycins, aminoglycosides $[3,13]$. The majority of drugs obtained from microorganisms are used against other microorganisms, but some isolated substances have become lead compounds for differently pharmacological active drugs, for example: asperlicin derived from Aspergillus alliaceus became a lead compound in obtaining an antagonist for the cholecystokinin receptor CCKA - influencing hunger [14]. Scientists also draw inspiration from the sea world (corals and sponges), from animals (epibatidine - an alkaloid that is secreted by the Ecuadoran frog Epipedobates anthonyi) [15] or from venoms and toxins (teprotide - isolated from the snake Bothrops jararacacontributed to discovery of cilazapril and captopril, which are ACE inhibitors) [16]. Another source of lead compounds are thousands existing synthetic compounds, synthesized by pharmaceutical companies and university laboratories all over the world. These substances are obtained as reaction intermediates, which does not exclude their pharmacological activity [3].

\section{“ME TOO” DRUGS}

A number of pharmaceutical companies uses the valued drugs of their competitors as lead compounds, modifying them and registering the changed drugs on the market. In so-doing, the substance has to be modified in such a way that it will not infringe patent protection but will still retain bioactivity. Such drugs are often unjustly called "me too" drugs, because they are frequently better than original, for example, new penicillins are more selective and stronger than the prototype $[3,17]$.

\section{USEFUL SIDE EFFECTS}

Side effects can also be a starting point for further research. The aim of such research will be intensifying those side effects, while at the same time eliminating previous activity. For example, modifications eliminating the antibacterial activity of sulfonamides while simultaneously intensifying hypoglycemic activity, resulted in the discovery of tolbutamide [18].

That is why a certain structure should not be assigned one direction of bioactivity, and the precise observation of all directions of activity is necessary. In some cases, the natural ligand of a target receptor can become the lead compound. 
Serotonin was the lead compound in the discovery of the 5HT1 receptor agonist - sumatriptan, while noradrenaline was used in the search for the $\beta$-agonist - salbutamol and dobutamine [19].

Still, there are a lot of receptors which the natural ligands are not known. These are called "orphan receptors". Identification of such ligands will provide the opportunity of discovering new drugs. Similarly, natural substrates and products of enzymes, or natural modulators are used as lead compounds [3].

\section{COMBINATORIAL CHEMISTRY}

Unfortunately, traditional methods of searching for lead compounds are left behind in the improving knowledge about the human genome and related potential drug targets. This has led to the emergence of a new branch of chemistry. Combinatorial synthesis is a solid-phase procedure that allows the production of many substances in sub-micro amounts in a short time. Its aim is to research their influence on specific receptors. The methods used to measure activity (FIA, RIA) are exceptionally sensitive and use pmol amounts. High Throughput Screening (HTS) leads to miniaturization and automation of the testing, and allows the testing of numerous samples. Reactions are conducted small scale and produce a mixture of compounds [20].

Current drugs are often being designed with the help of molecular modeling. Its components are, among others, molecular graphics and issues related to the realistic visualization of the examined particles. Using the massive computing powers of modern super-computers allows to change the shape of potential new drugs to better fit its receptor and to improve its pharmacokinetic properties. Since there are infinitely many obtainable derivatives, therefore, it is reasonable to determine which substituents should be in new compounds. The solution to this problem is the determination of the physicochemical properties on the basis of the structure - the Quantitative Structure-Activity Relationship (QSAR). Finding these kinds of relationships in a group of compounds and describing them via mathematical equation allows to specify the meaning of certain properties for biological activity. It also enables the prediction of the structure of new compounds with a given mechanism of action. The biggest advantage of QSAR is reducing the number of synthesized analogs needed for testing [3,21].

Computer programs also offer the opportunity to analyze the likelihood of the receptor connecting with the test chemical molecule to the receptor site. Known amino acid sequences are collected and made available through public and specialized databases such as the Protein Data Bank http://www.pdb.org, or ExPASy (Expert Protein Analysis System) - http://www.expasy.org. Based on the shape and properties of the receptor binding sites, the chemical structure of the potential drug is planned and is compiled with a virtually reproduced digital computer model of the receptor. To make this possible, it is necessary to identify and define the exact binding site - the element of the structure which is responsible for linking with the drug. Among the used methods, the most important are based on homology; that is comparing the unknown to the known structures of the binding sites $[22,23]$.

\section{THE IDENTIFICATION OF PHARMACOPHORE}

After determining which groups are necessary for the given direction of biological activity, the next step is to identify a group of pharmacophores. By analogy with term 'chromophore', known in organic chemistry for more than 100 years, molecular pharmacology has introduced the concept of the 'pharmacophore'. It is the minimal part of a molecule of a biologically active compound that is responsible for the presence of the biological effect. The location of particular spheres, determining a pharmacophore's properties, is defined by the distance between them. The pharmacophore is obtained by identifying the structures of the active compounds and noticing their common characteristics. The activity of new compounds is then evaluated by imposing them on the pharmacophore. The process of searching for pharmacophores uses advanced mathematical methods computational intelligence or genetic algorithms, and is based on the findings regarding the biological inheritance of traits [24].

\section{TARGET-ORIENTED DRUG DESIGN}

Knowledge of the structure of the pharmacophore and its binding groups allows the synthetization of the analogues of the leading compound containing this particular pharmacophore. This step seems to be unnecessary. Why continue looking for new compounds if you were able to find a working molecule? The answer is that in modifying the lead structure, the aim is to increase the biological activity of the new drug, reduce possible side effects, make it patientfriendly and easy-to-produce. Several methods of modification are known. Such a selected compound or several compounds are subsequently considered candidates for potential drugs and are then tested in more complex models, as well as on animals. Of note, only substances seen to be active via classical pharmacological testing can undergo further preclinical and clinical trials involving humans [25].

\section{PRECLINICAL TRIALS}

Before the new drug is admitted for use in humans it has to pass a series of rigorous pharmacological and toxicological tests called 'preclinical trials'. This usually starts with in vitro tests on genetically engineered cell cultures in order to check for drug effects on reproduction or carcinogenesis. In recent years, biochemical analyzes, as well as studies of molecular biology are being more commonly and frequently used. Employment of these methods comes with a number of advantages: first of all, it allows for faster and more accurate characterization of the drug activity than do traditional methods. Secondly, scientists can reject substances which engender side effects or are insufficiently active. The result is an acceleration of research and a reduction in financial expenses. Still predicting of the pharmacokinetics or adverse reactions on the basis of a chemical structure is possible only approximately, therefore, studies on animals or on isolated 
organs are still a necessity. The main purpose of the preclinical trials is to determine the safety of drugs in humans and to confirm the direction of their therapeutic action [3,27].

The test results, the possibility of extrapolation to humans and the costs depends mainly on the choice of appropriate species of animals and the organizations of research. The recommendation often suggests carrying out trials on two different species, from which one of them cannot be a rodent. However, the majority of experimental centers usually use small rodents (mice and rats) due to costs. Still, in order to develop a statistical result, a sufficiently large number of animals is required. In extremely important researches, substances are being tested on dogs and primates, in spite of expenses.

The animals chosen for testing should bear as close a resemblance to the human organism as possible, in relation to absorption, bioavailability, biotransformation, accumulation, excretion and possibly acute and long-term toxicity. Furthermore, animals of both sexes must be used in trials because of different enzyme activity and the influence of sex hormones. In addition, the test animals have to be young, sexually mature and have similar body weight $( \pm 10 \%)$.

Acclimatization in laboratory conditions takes a minimum of 5 days, after which the animals are randomly assigned to particular groups. In the lab and where the animals are housed, the average temperature should be $\pm 23^{\circ} \mathrm{C}$, relative humidity $30-70 \%$. The lighting ought to resemble natural light. The animals are also to be provided with unlimited supply of water and contamination-free fodder. For bona fide research, the control group has to stay in exactly the same environment as the experimental group [27].

\section{R'S}

Research conducted on animals follow the guidelines set by the principle of 3R's - Replacement, Reduction and Refinement. The 3R's notion stems from a 1959 report by Russell and Burch, titled 'The Principles of Humane Experimental Techniques' [28]. The authors proposed these suggestions as a way to make animal experiments more humane. The most important concept concerns the test animal's welfare, that is, quality of life. This includes the following: the animals should be healthy, well-fed, housed in an friendly environment that is relatively free from negative states (fear, pain, distress) and be able to carry out activities that they are strongly motivated to do. With passing of time, Russell and Burch's ideas were incorporated into legislation governing usage of animals in science. The 3R's demands are applied by scientists as they prepare written descriptions of their proposed animal-based studies and by animal care committees during their ethical review of the presented work [29].

\section{REPLACEMENT}

Replacement is defined as the methods that avoid the use of conscious living higher animals or the substitution of them with insentient material. To achieve these, many alternative methods can be employed. Among these are tissue culture and slices, cellular and subcellular fractions (in vitro biological systems), mathematical and computer models - predictive modeling and in silico simulation, immature forms of vertebrates (Danio rerio), as well as invertebrates (Drosophila). These tests are very useful in the initial stage of studies, before experiments that involve higher animals. They provide valuable information about intracellular processes, allow initial testing of toxicity and help in understanding the mechanisms of action of new drugs. However, individual cells react differently with respect to the whole body effect. Therefore, most of the results obtained in vitro must be repeated in vivo, i.e. on the living organism. Nowadays, scientists are attempting to create something like an artificial organism on which test material can be assessed, but, unfortunately, this is not yet in the realm of reality. For now, it is not possible to replace animal research, because the living organism is a system of various structures connected with each other on so many levels that it is impossible to reproduce under artificial conditions. It is, thus, impossible to transfer the conclusions from research on cell cultures directly to humans, as, by studying a compound at the laboratory scale, we are not able to predict its effects on the whole organism.

In addition, animal testing is also required by law when registering drugs. These include toxicity tests, studies on the effects on offspring in subsequent generations, teratology testing, or studying the effect of the new drug on the embryo or fetus. These tests allow to trace any toxic effects that may induce congenital anomalies [29,30].

\section{REDUCTION}

The aim of reduction is to minimize the number of animals needed in testing to obtain the same information. Reduction is possible due to better experimental design, improved statistical methods and the sharing of data. Thus, in line with the notion of reduction, research groups and organizations should not repeat each other's studies unnecessarily. It must be understood, however, that the curtailment of the number of animals cannot increase the pain suffered by the individual animal.

How many animals should be used? The answer is ruled by statistics. The smallest number is five, but sometimes an individual animal must be excluded from the research study, for example, because it behaves quite differently. Thus, five animals are usually not enough. Here, the researcher's experience and research planning is important so as to use the optimal number of animals. The bottom-line is that individual fields of science still require a specific approach and researcher experience.

The number of animals that should be used for research is always widely consulted with authorities in a particular field and must be selected to the requirements of the experiment.

However, sometimes the law specifies how many animals and which sex should be used in a study - for example, in evaluating the toxicity of a 28-day repeated dose (subchronic toxicity), three doses of the test substance should be used, with each dose given to five male and five female test animals $[29,30]$. 


\section{REFINEMENT}

The term 'refinement' includes all methods that lead to limiting the pain, stress and suffering felt by test animals. The principles of refinement are applied to various aspects of animal use, and are manifested by procedures such as training animals to cooperate with scientists, providing them with housing suited to their needs and behavior or the usage of anesthetics and analgesics. Herein, the stressing factor for the animal can be almost everything - a raised voice, a door slammed shut, temperature. Conducting the research according to $3 \mathrm{R}$ principles aims not only at humanizing the test animals' conditions, but also at improving the quality and reproducibility of the experiments they are used for $[27,29,30]$.

\section{DANIO RERIO}

Despite the existing pre-eminence of mouse in modeling human disease, more often, other, more humane animal models are being used by scientists in research and drug development. One of these animals is the zebrafish (Danio rerio). This has become a widely used model organism. Because of their fecundity and biology, research groups are able to follow the fish through all of its developmental stages. Moreover, their transparent skin allows the tracing of developing pathologies in real-time. Another quality that makes them valuable is the similarity of their genome to that of human beings. Indeed, $70 \%$ of all protein-coding human genes are related to genes found in Dario rerio, while $84 \%$ of all genes evoking human diseases have a zebrafish counterpart. Because of these traits, zebrafish are being used in a number of ways, such as target identification, lead discovery, disease modeling and toxicology [31-34].

\section{DROSOPHILA MELANOGASTER}

Another example of replacing conscious higher living animals with less conscious is the use of the common fruit fly (Drosophila melanogaster). The common fruit fly shares a lot of basic biological, physiological and neurological properties with mammals, while almost $75 \%$ of human disease-causing genes can be found in D. melanogaster. Moreover, the fly is a well-known and highly tractable genetic model in studying the mechanisms of human diseases. An advantage of using this model is lowering of the costs of conducting experiments, as well as the fact that the fly is suitable for drug screening and target discovery [35].

\section{CLINICAL TRIALS}

If a new substance passes pre-clinical trials, the research group can apply for the substance to be allowed to go to clinical trials. Many promising drugs fail at this trial stage, which leads to different analogues being submitted until one can be clinically approved. Clinical trials consist of testing potential drug on healthy volunteers and/or volunteer patients. The testing must meet ethical standards and volunteers must give consent. The testing also must be in compliance with the formal rules of clinical trials [36].
The rules of clinical trial conduction were systematized following the disastrous release to market of thalidomide from the early 1960s. A key document with regard to the ethics of biomedical research was the Helsinki Declaration, originally adopted in 1964. This served as a basis for articulating the rules of Good Clinical Practice (GCP). GCP is a international standard defining the way in which clinical trials should be conducted, the rules of monitoring and of oversight of trials, record keeping, methods of data analysis and ethical aspects. Following the GCP guarantees credibility and preciseness of obtained data, and respect of the human rights of test subjects. New drugs are mostly evaluated by way of Randomized Controlled Trials (RCT). The participants of the trial are randomly assigned to either a group receiving the new substance or to a control group that is being given standard or placebo treatment. Generally, the experiment is a double-blind. Randomization reduces bias, while the existence of different comparison groups allows to determine any effects of the treatment in relation to the control group [24]. The process of the trial is long (about 5-7 years), requires the commitment of many clinics and of hundreds to thousands of patients from different places in the world. It is vastly expensive. RCT consists of four phases.

\section{Phase I}

The potential drug is used for the first time by humans. The trials conducted during Phase I are mostly concerned with safety rather than effectiveness. They are carried out on healthy volunteers, however, if the drug is potentially toxic but it can be used to save lives, for example, in diseases such as cancer or AIDS, the volunteers are patients. The main goal of these Phase I trials is finding the effective dose which does not cause serious side-effects. These studies also provide basic pharmacokinetic data concerning liberation, absorption, distribution, metabolism and excretion. Volunteers commit to not taking other medication, drinking coffee and alcohol and smoking. This pre-cautions allow to exclude other factors that may cause side-effects. Of note, beyond the aforementioned, Phase I research provides information about bioavailability and interaction with food [36-38].

\section{Phase II}

Research during Phase II is aimed at confirming the safety of the new drug and obtaining data about its efficiency. Patients taking part in tests must pass rigorous criteria that are to eliminate factors disturbing the evaluation of effectiveness. Phase II studies usually take about two years and can be divided into early (IIa) and late (IIb) studies. Phase IIa trials are carried out on a limited number of patients in order to ascertain whether the drug actually has any therapeutic value, and to observe potential side effects. They are followed by later studies (Phase IIb), that, in contrast, involve a larger number of patients. Strict monitoring of each patient is required, and the number of patients usually is from 100 to 200 [36-38].

\section{Phase III}

If the submitted drug shows positive results in the Phase II trials, research is taken among a larger population of patients. The statistics generated in Phase III trials serve 
as the basis for registering the drug. This research can take up to three years. Phase IIIa trials assess if any beneficial effect is caused or not caused by the drug. During this stage, doctors may tweak dose levels to find the optimal. In the time between registration and approval of a drug, Phase IIIb begins. This phase aims to understand if the drug is really effective in comparison to standard treatment. Even during this stage, grave side-effects may be observed. If so, the drug does not go to market. A prime example of such event is Pfizer's torcetrapib After 16 years of development at a cost of $\$ 800$ million, further work on it was terminated because there was a statistically increased risk of death associated with its use [36-38].

\section{Phase IV}

Phase IV includes studies conducted after bringing the drug into the market. The intent of this research is to broaden the knowledge about the product. This comes about because a Phase IV trial involves a large number of patients using the drug over a longer period of time. Clinical trials of Phase IV are often conducted on specific demographics: the elderly, children, pregnant women and people taking other medication. The research allows identifying and measuring unique and long-term effects. Additionally, during Phase IV research it is possible to discover new activity. This procedure allows the discovery of serious side-effects that were not evident earlier. An example of a Phase IV termination is that of practolol. This was withdrawn from the market after few years of being available, because some patients lost sight - the cause of blindness is still unknown [36-38].

\section{PHARMACOVIGILANCE (PV)}

The World Health Organization (WHO) plays supervisory role over the safety of pharmacotherapy. WHO is supported by the WHO Collaborating Centre for International Drug Monitoring in Uppsala in promoting 'pharmacovigilance' at the country level. According to WHO: 'pharmacovigilance (PV) is defined as the science and activities relating to the detection, assessment, understanding and prevention of adverse effects or any other drug-related problem.' As of the end of 2010, 134 countries have become enrolled in the WHO Pharmacovigilance Programme [39].

\section{PATENT}

If a pharmaceutical company wants to enjoy the exclusive benefits of placing a drug on the market, it must obtain a patent - the right to protect the invention. Once a patent is obtained, the company has the exclusive right to manufacture and sell its invention for a specific period of time (in most countries it is 20 years). It is very important to file a patent application in the shortest possible time, as the competition between pharmaceutical companies creates a real chance that the same drug could be discovered in another company, only a little later. If a company does not acquire exclusive rights, competing companies will enter the market with the same, but much cheaper product. Therefore, the price of the new medicine does not only cover the costs incurred, but also the large profits that will cover the costs of subsequent research projects, as well as the passage of the procedures described in this article, required for the introduction of a new medicine $[3,40]$.

\section{REFERENCES}

1. Schultes RE. The appeal of peyote (Lophophora williamsii) as a medicine. Am Anthropol. 1938;4:698-715.

2. Scarborough J. Drugs and medicines in the roman world. Expedition. 1996:38-51.

3. Patrick GL. An Introduction to Medicinal Chemistry. Wyd. 5. Oxford University Press; 2013.

4. Zając M, Pawełczyk E, Jelińska A. Chemia leków dla studentów farmacji i farmaceutów. Wyd. 2. UM Poznań; 2006.

5. Mutschler E, Geisslinger G, Kroemer HK, Ruth P, Schaefer-Korting M. Farmakologia i toksykologia. Wyd. 3. Wrocław: Elsevier; 2012.

6. Silverman RB. Chemia organiczna w projektowaniu leków. Warszawa: Wydawnictwo Naukowo-Techniczne; 2004.

7. Ghofrani HA, Osterloh IH, Grimminger F. Sildenafil: from angina to erectile dysfunction to pulmonary hypertension and beyond. Nat Rev Drug Discov. 2006;5:689-702.

8. Matosiuk D, Fidecka S, Antkiewicz-Michaluk L, Dybala I, Koziol AE. Synthesis and pharmacological activity of new carbonyl derivatives of 1-aryl-2-iminoimidazolidine. Part 3. Synthesis and pharmacological activity of 1-aryl-5,6 $(1 \mathrm{H})$ dioxo-2,3-dihydroimidazo [1,2-a]imidazoles. Eur J Med Chem. 2002;37:845-53.

9. Altshuler D, Daly MJ, Lander ES. Genetic mapping in human disease. Science, 2008;322:881-8.

10. Bodera P, Chcialowski A. Immunomodulatory effect of probiotic bacteria. Recent Pat Inflamm Allergy Drug Discov. 2009;3:58-64.

11. Willson TM, Brown PJ, Sternbach DD, Henke BR. The PPARs: from orphan receptors to drug discoveryJ Med Chem. 2000;43:527-50.

12. Shi Y. Orphan nuclear receptors in drug discovery. Drug Discov Today. 2012;12:440-45.

13. Chin YW, Balunas MJ, Chai HB, Kinghorn AD. Drug discovery from natural sources. AAPS J. 2006;8:E239-E253.

14. Zucker KA, Adrian TE, Zdon MJ, Ballantyne GH, Modlin IM. Asperlicin: a unique nonpeptide cholecystokinin antagonist. Surgery. 1987;102:163-70.

15. Fitch RW, Spande TF, Garraffo HM, Yeh HJ, Daly JW. Phantasmidine: an epibatidine congener from the Ecuadorian poison frog Epipedobates anthonyi. J Nat Prod. 2010;73:331-7.

16. Kostis JB. Angiotensin converting enzyme inhibitors. I. Pharmacology. Am Heart J. 1988;116:1580-91.

17. Hollis A. Me-too drugs: is there a problem. WHO report. 2004.

18. Drews J. Drug discovery: a historical perspective. Science. 2000;287: 1960-64.

19. Warne T, Moukhametzianov R, Baker JG, Nehmé R, Edwards PC, Leslie AG et al. The structural basis for agonist and partial agonist action on a $\beta$ 1-adrenergic receptor. Nature. 2011;469:241.

20. Plunkett MJ, Ellman JA. Chemia kombinatoryczna i nowe leki. Świat Nauki. 1997;6:26-31.

21. Cherkasov A, Muratov EN, Fourches D, Varnek A, Baskin II, Cronin $\mathrm{M}$ et al. QSAR modeling: where have you been? Where are you going to? J Med Chem. 2014;57:4977-5010.

22. Polak S, Wiśniowska B. Modelowanie komputerowe w badaniach nad lekiem - projektowanie i poszukiwanie cząstki aktywnej, ocena właściwości fizykochemicznych oraz aktywności biologicznej. Farm Pol. 2009;65:214-23.

23. Gruca A. Bioinformatyczne bazy danych. Warszawa: Wydawnictwo Polsko-Japońskiej Akademii Technik Komputerowych; 2010.

24. Berlicki L, Kafarski P. Computer-aided analysis and design of phosphonic and phosphinic enzyme inhibitors as potential drugs and agrochemicals. Curr Org Chem. 2005;9:1829-50.

25. Vogel G. Phylogenetic analysis: getting its day in court. Science. 1997;275:1559-60.

26. Honek, J. Preclinical research in drug development. Medical Writing. 2017;26:5-8. 
27. Seńczuk W. Toksykologia współczesna. Warszawa: Państwowy Zakład Wydawnictw Lekarskich; 2012.

28. Russell WMS, Burch RL. The Principles of Humane Experimental Technique. London: Methuen \& Co. Special edition published by Universities Federation for Animal Welfare (UFAW);1992.

29. Schollenberger A. Zasada 3R w ochronie zwierząt wykorzystywanych do badań naukowych. Życie Weterynaryjne. 2017;92.

30. Rusche $B$. The 3 Rs and animal welfare-conflict or the way forward. Altex. 2003;20:63-76.

31. Dodd A, Curtis PM, Williams LC, Love DR. Zebrafish: bridging the gap between development and disease. Hum Mol Genet. 2000;9:2443-9.

32. Zon LI, Peterson RT. In vivo drug discovery in the zebrafish. Nat Rev Drug Discov. 2005;4:35-44.

33. Lieschke G, Currie PD. Animal models of human disease: zebrafish swim into view. Nat Rev Genet. 2007;8:353-67.
34. Howe K, Clark MD, Torroja CF, Torrance J, Berthelot C, Muffato M et al. The zebrafish reference genome sequence and its relationship to the human genome. Nature. 2013;496:498-503.

35. Pandey BU, Nichols CD. Human disease models in Drosophila melanogaster and the role of the fly in therapeutic drug discovery. Pharmacol Rev. 2011;63:411-36.

36. Brodniewicz T. Badania kliniczne. Wyd 1. Warszawa. CeDeWu. 2015.

37. Jachowicz R. Farmacja praktyczna. Warszawa: Państwowy Zakład Wydawnictw Lekarskich; 2007.

38. Mahan V. Clinical trial phases. Int J Clin Med. 2014;5:1374-83.

39. National Centre for the Replacement, Refinement and Reduction of Animals in Research. https://www.nc3rs.org.uk/the-3rs (stan z 01.03.2018).

40. Portal Farmaceutyczno-Medyczny. Patent na lek. https://www.pfm. pl/artykuly/patent-na-lek/275 (stan z 01.03.2018). 